Article

\title{
Pilot Scale Testing of Adsorbent Amended Filters under High Hydraulic Loads for Highway Runoff in Cold Climates
}

\author{
Carlos Monrabal-Martinez *, Aamir Ilyas and Tone M. Muthanna \\ Department of Civil and Environmental Engineering, Norwegian University of Science and Technology, \\ 7491 Trondheim, Norway; aamir.ilyas@ntnu.no (A.I.); tone.muthanna@ntnu.no (T.M.M.) \\ * Correspondence: carlos.monrabal@ntnu.no; Tel.: +47-735-947-45
}

Academic Editor: Glenn Brown

Received: 2 January 2017; Accepted: 19 March 2017; Published: 22 March 2017

\begin{abstract}
This paper presents an estimation of the service life of three filters composed of sand and three alternative adsorbents for stormwater treatment according to Norwegian water quality standards for receiving surface waters. The study conducted pilot scale column tests on three adsorbent amended filters for treatment of highway runoff in cold climates under high hydraulic loads. The objectives were to evaluate the effect of high hydraulic loads and the application of deicing salts on the performance of these filters. From previous theoretical and laboratory analysis granulated activated charcoal, pine bark, and granulated olivine were chosen as alternative adsorbent materials for the present test. Adsorption performance of the filters was evaluated vis-à-vis four commonly found hazardous metals $(\mathrm{Cu}, \mathrm{Pb}, \mathrm{Ni}$ and $\mathrm{Zn})$ in stormwater. The results showed that the filters were able to pass water at high inflow rates while achieving high removal. Among the filters, the filters amended with olivine or pine bark provided the best performance both in short and long-term tests. The addition of $\mathrm{NaCl}(1 \mathrm{~g} / \mathrm{L})$ did not show any adverse impact on the desorption of already adsorbed metals, except for $\mathrm{Ni}$ removal by the charcoal amended filter, which was negatively impacted by the salt addition. The service life of the filters was found to be limited by zinc and copper, due to high concentrations observed in local urban runoff, combined with moderate affinity with the adsorbents. It was concluded that both the olivine and the pine bark amended filter should be tested in full-scale conditions.
\end{abstract}

Keywords: stormwater runoff; alternative adsorbents; pilot scale; hydraulic loading; adsorption; service life; toxic metal removal

\section{Introduction}

Infiltration based solutions have been shown to be an efficient method for treating hazardous substances from stormwater in urban areas [1-4]. These solutions include different forms and functions, depending on the area of application, such as rain gardens, bioretention swales, and infiltration trenches, etc. Infiltration based stormwater options aim to restore/mimic pre-development conditions [5] by reducing runoff volumes, trapping sediments, and mitigating peak flow rates. In some cases, infiltration based systems are also designed to remove dissolved contaminants by adding a specific adsorbent layer [6], or relying on combined effects of plants and soils-bioretention [7]. Heavy metals are found in urban runoff from multiple nonpoint sources such as vehicle components wear, exhaust emissions, lubricants, and galvanized elements along roads, among others [8]. The presence of these metals vary in both spatial and temporal resolution, as well as phase (particulate and dissolved forms). It is the latter form that is the most bioavailable and hazardous for biota [1,9]. 
A wide range of materials have been identified and tested for their performance for removal of heavy metals [10], nutrients [11], and organic contaminants [12], among others. These adsorbents materials include secondary wastes, minerals, and biological materials. Generally, adsorption processes are dependent on the specific surface area of the material, which increases with decreasing particle size. However, a decrease in the particle size leads to a lower hydraulic conductivity of the filters. In stormwater solutions that are designed for a certain allowable ponding, such as bioretention areas, wetlands, and detention ponds, a lower hydraulic conductivity and larger surface area can be adequate given the pooling capacity of such facilities. On the other hand, in areas close to road surfaces or systems with no ponding capacity, the runoff must be infiltrated as quick as possible for safety issues. Therefore, high hydraulic conductivity is an important design feature to allow for a high hydraulic loading. This favors adsorbents with a larger particle size.

For the end user, the service life of the infiltration based facility is also highly relevant, because it is an important factor in the selection decision. The service life of an adsorbent/filter is mainly determined by a combination of pollutant concentration in the effluent, pollutant accumulation in the filter, and loss of infiltration potential due to clogging [13]. Several studies have been undertaken to quantify the service life of the filters from the pollution perspective [13-16]. Batch studies might be used to preselect potential adsorbents based on adsorption criteria. Generally, isotherm models are adopted to fit experimental batch data. However, these models are meant for gas adsorption on solid surfaces, which differs from solution-solid conditions occurring in infiltration based systems. Additionally, assumptions made by isotherm models will introduce uncertainties when determining adsorption capacities of adsorbents. In contrast, column studies, which are also laboratory based tests, can best reproduce field conditions of varying inflows, increasing liquid to solid ratios over time, and inducing dynamic conditions. Breakthrough curves obtained from column studies can help determine the volume of water treated before the filter no longer can meet a certain pollutant removal in the effluent. On the other hand, high intensity inflows, freezing-thawing cycles, and application of deicing salts are generally ignored during the evaluation of the performance of these filters, which can affect the adsorbent performance. Consequently, this poses an obstacle for an appropriate design of infiltration based facilities.

This study evaluated three filters composed of sand and three alternative adsorbents (pine bark, olivine, and charcoal) in a pilot scale column study under high hydraulic loads. The adsorbents were identified in a previous study, which used multicriteria analysis and batch tests to evaluate the upscaling potential of eight adsorbent materials [17]. In the first phase of the study, the influence of high hydraulic loads as well as deicing salts over the pollutant retention was evaluated. In the second phase, the long-term performance was studied in order to obtain data for estimating the service life of the materials.

\section{Materials and Methods}

\subsection{Adsorbent Materials}

All the adsorbent materials and the sand (Table 1) were obtained by commercial suppliers locally. The granulated activated charcoal (extracted from anthracite coal) was a Sigma Aldrich AS product (Oslo, Norway), the sand was manufactured by Rådasand AB (Lidköping, Sweden), the pine bark Pinus Sylvestris was provided by Nittedal Torvindrustrie AS (Bjørkåsen, Norway), and the olivine was supplied by Sibelco Nordic AS (Rud, Norway) and belongs to the Blueguard ${ }^{\circledR}$ series. Charcoal and olivine were used without any chemical processing or modification. While, pine bark was sieved $<4 \mathrm{~mm}$ particle size prior to use in order to favor water retention. The adsorbents were placed in pilot scale columns with clean quartz sand, which was selected for its uniform particle size and little or no background contamination. Therefore, the influence of the sand on the hydraulic conductivity and removal performance was assumed homogeneous throughout the study. 
Table 1. Material properties of the sand and adsorbents used in the study. UC stands for uniformity coefficient.

\begin{tabular}{|c|c|c|c|c|}
\hline Parameter & Sand & Olivine & Charcoal & Pine Bark \\
\hline Particle Density ${ }^{\alpha}\left(\mathrm{g} / \mathrm{cm}^{3}\right)$ & 2.66 & 3.12 & 1.91 & - \\
\hline Max Dry Density ${ }^{\beta}\left(\mathrm{g} / \mathrm{cm}^{3}\right)$ & 1.77 & - & - & - \\
\hline Bulk density $\left(\mathrm{g} / \mathrm{cm}^{3}\right)$ & 1.48 & 1.62 & 0.44 & 0.24 \\
\hline $\mathrm{D}_{90}{ }^{\gamma}(\mathrm{mm})$ & 0.65 & 1.93 & 1.83 & - \\
\hline $\mathrm{D}_{60} \gamma(\mathrm{mm})$ & 0.403 & 1.53 & 1.33 & - \\
\hline $\mathrm{D}_{10}^{\gamma}(\mathrm{mm})$ & 0.183 & 0.903 & 0.73 & - \\
\hline $\mathrm{UC}\left(\mathrm{D}_{60} / \mathrm{D}_{10}\right)$ & 2.22 & 1.66 & 1.85 & - \\
\hline BET Surface Area ${ }^{\delta}\left(\mathrm{m}^{2} / \mathrm{g}\right)$ & 0.564 & 4.264 & 881.964 & 0.444 \\
\hline
\end{tabular}

Notes: ${ }^{\alpha}$ Data from the present study obtained with pycnometer test; ${ }^{\beta}$ Data from the present study obtained with proctor compaction test; $\gamma$ Data from the present study obtained from particle size distribution curves; ${ }^{\delta}$ Data from the present study obtained with Brunauer-Emmett-Teller (BET) test.

\subsection{Column Tests}

The adsorbents were tested for removal of four dissolved metals $(\mathrm{Cu}, \mathrm{Pb}, \mathrm{Ni}$, and $\mathrm{Zn})$ commonly found in urban and highway runoff and of environmental concern for official authorities due to their toxicity towards the biota in the receiving water bodies. For the column tests, synthetic stormwater was prepared in a large tank $\left(1 \mathrm{~m}^{3}\right)$ by mixing tap water with a stock solution containing the metals. Metal chloride salts were used for preparing the stock solution, and were chosen for the additional benefit of simulating salts in stormwater. On the other hand, tap water contains other major ions $\left(\mathrm{Na}^{+}\right.$, $\mathrm{Ca}^{2+}$, etc.), which makes it a realistic surrogate for actual stormwater (Table 2). The target metals were added in a quantity to achieve intended concentration of $1 \mathrm{mg} / \mathrm{L}$ for each metal in the $1 \mathrm{~m}^{3}$ influent tank. The reason behind this high concentrations was to be able to obtain detectable concentrations in the outflow and early breakthroughs because high adsorption was expected in the filter based on prior batch tests [17]. The $\mathrm{pH}$ of the synthetic stormwater was approx. 7.5, which is similar to values observed in local urban runoff.

Table 2. Major constituents in the tap water.

\begin{tabular}{cc}
\hline Parameter & Concentration $(\mathrm{mg} / \mathrm{L})$ \\
\hline Calcium & 21.7 \\
Sodium & 4.45 \\
Magnesium & 0.89 \\
Potassium & 0.45 \\
Chloride & 7.46 \\
Sulphate & 2.5 \\
\hline
\end{tabular}

Plexiglas columns with $45 \mathrm{~cm}$ length and $10 \mathrm{~cm}$ diameter were constructed and used in the study. The columns were filled with $35 \mathrm{~cm}$ sand overlying $5 \mathrm{~cm}$ of adsorbent (see Figure 1). Adsorbent placement at the bottom will protect the material from eventual frost and erosion. In addition, bottom placement for pine bark means less oxidation problems as lower zones will remain wetter with lower $\mathrm{O}_{2}$ availability. The length $(40 \mathrm{~cm})$ represents minimum recommended depth for bioretention facilities in Norwegian climate [18], where these filters might potentially be used.

Three columns were set up for each filter media including a control column that was packed only with sand. All columns were operated at room temperature $\left(20 \pm 2{ }^{\circ} \mathrm{C}\right)$ and the tap water used to produce the synthetic stormwater was at $8 \pm 2{ }^{\circ} \mathrm{C}$. Multichannel peristaltic pumps with variable flow were used for pumping the synthetic stormwater. The flow rates were based on the saturated hydraulic conductivity $\left(\mathrm{K}_{\mathrm{sat}}\right)$ of each filter, which has been investigated separately [19]. Therefore, full infiltration at the largest possible inflow rate was intended with no visible ponding water. 


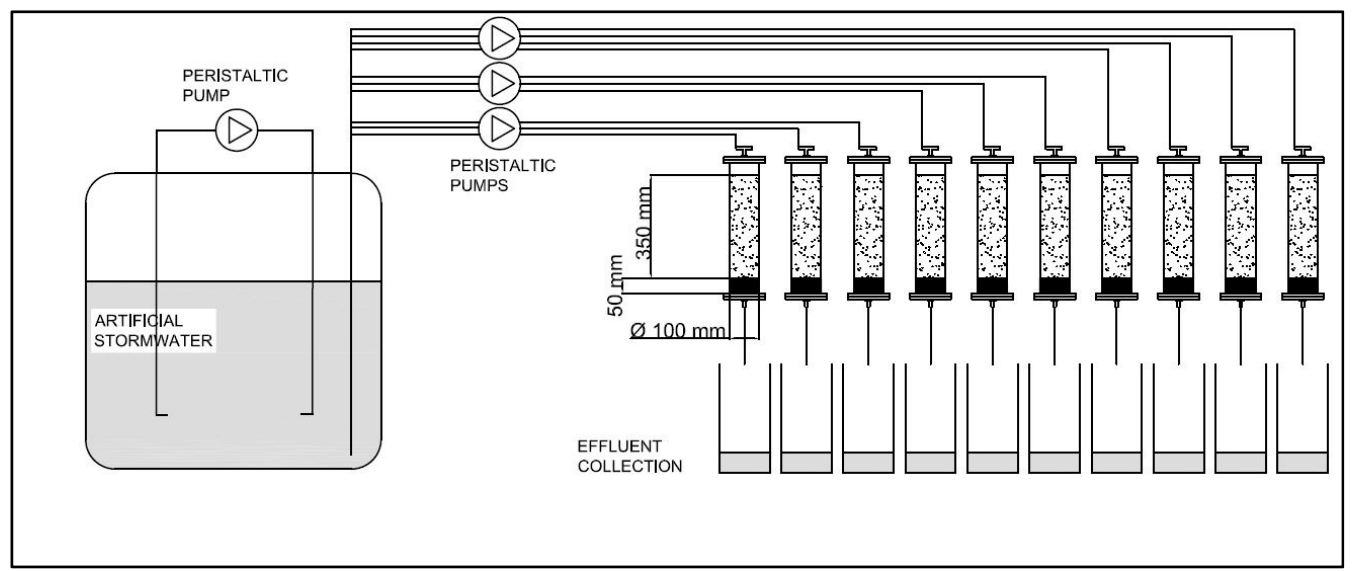

Figure 1. Schematic overview of the column setup with adsorbents placed at the bottom.

The study was divided in two phases. In the first phase flow rates, supplied by the peristaltic pumps, were controlled and set at the $\mathrm{K}_{\text {sat }}$ of each filter. The objective was to verify the adsorption capacity of the filters under high hydraulic loads, specifically under the largest inflow rate that is expected to not generate water ponding. The experimental columns were continuously run for approx. $14 \mathrm{~h}$, and each column received a water volume of approx. $50 \mathrm{~L}$ (liquid to solid ratio LS = 11). After passing this volume of water, one of the two duplicate columns for each media was taken aside to study the effect of road salt on the desorption of already immobilized metals. For the salt experiment, the columns were initially fed with approx. $50 \mathrm{~L}(\mathrm{LS}=11)$ of plain tap water, and then with the same amount of a solution composed of tap water with $1 \mathrm{~g} / \mathrm{L} \mathrm{NaCl}$. The concentration of $\mathrm{NaCl}$ was based on common concentrations found in highway stormwater in Norway, similar to the value adopted by previous studies [20]. In the second phase, long-term operation was the objective, and the study continued in each of the remaining columns for 2.5 months (Table 3). Samples were collected biweekly from the effluents of every column and analyzed for the target metals. After the collection, $\mathrm{pH}$ and electroconductivity of the samples were measured, then samples were filtered through $0.45 \mu \mathrm{m}$ pore membrane filters for analyzing dissolved fraction of the studied target metals, and preserved with $0.1 \mathrm{M}$ $\mathrm{HNO}_{3}$ acid. Samples were stored at $4{ }^{\circ} \mathrm{C}$ until the analysis with a high resolution inductive coupled plasma HR-ICP-MS instrument from Thermo Fisher Scientific AS (Oslo, Norway). Each individual sample was scanned three times and the results were corrected for blank samples. The quantification detection limits for $\mathrm{Ni}, \mathrm{Zn}, \mathrm{Cu}$ and $\mathrm{Pb}$ was $0.015,0.025,0.03$, and $0.002 \mu \mathrm{g} / \mathrm{L}$, respectively.

Table 3. Average volume per column (AV) and hydraulic loading rate (HLR) used during the two phases of the study. CRT stands for column running time.

\begin{tabular}{ccccc}
\hline Influent Type & Experiment Phase & AV (L) & HLR (cm/h) & CRT (Days) \\
\hline Synthetic stormwater & 1 & 50 & 47 & 0.6 \\
Salt water & 1 & 50 & 47 & 0.6 \\
Synthetic stormwater & 2 & 2500 & 18.8 & 73 \\
\hline
\end{tabular}

Similar column studies of metal adsorption and nutrient removal are found in the literature (Table 4). In this study, long-term data was needed to explore the exhaustion capacity of the studied filters because input concentrations were low in comparison to the other studies. On the other hand, high hydraulic rates were used to study the removal capacity of these filters under intense inflow rates with expected lower contact times with the filter. 
Table 4. Experimental characteristics of similar column studies. AV stands for average volume per column, HLR for hydraulic loading rate, CRT for column running time, IC stands for input concentration, MD for media depth, $\mathrm{CD}$ for column diameter, and TP for target pollutants.

\begin{tabular}{cccccccc}
\hline AV $(\mathbf{L})$ & $\begin{array}{c}\text { HLR } \\
(\mathbf{c m} / \mathbf{h})\end{array}$ & $\begin{array}{c}\text { CRT } \\
\text { (Days) }\end{array}$ & IC $(\mathbf{m g} / \mathbf{L})$ & MD (cm) & CD (cm) & TP & Reference \\
\hline 120 & 70.8 & 27 & $5-16$ & 23 & 1.8 & MTBE, Naphthalene, Zn & {$[15]$} \\
480 & 10 & 90 & 1 & 20 & 5.08 & $\mathrm{Cd}, \mathrm{Cu}, \mathrm{Pb}, \mathrm{Zn}$ & {$[13]$} \\
300 & - & 70 & $0.004-0.28$ & 800 & 37.7 & $\mathrm{Cd}, \mathrm{Cu}, \mathrm{Pb}, \mathrm{Zn}$ & {$[21]$} \\
158 & 124 & 30 & $2.5-5$ & 40 & 2 & $\mathrm{Cu}, \mathrm{Ni}, \mathrm{Zn}$ & {$[22]$} \\
300 & 4.1 & 183 & $0.048-0.6$ & 31 & 31 & $\mathrm{Zn}, \mathrm{Cu}, \mathrm{Pb}, \mathrm{Cd}$ & {$[23]$} \\
9 & 1.06 & 2 & $0.08-0.6$ & 3.5 & 1.9 & $\mathrm{Zn}, \mathrm{Pb}, \mathrm{Zn}$ & {$[14]$} \\
2550 & 18.8 & 133 & 1 & 40 & 10 & $\mathrm{Zn}, \mathrm{Pb}, \mathrm{Ni}, \mathrm{Cu}$ & This study \\
\hline
\end{tabular}

\subsection{Hydrological Perspective}

In order to relate the simulated flows back to the dimension of the storm events, the following hydraulic approach is presented. This approach is connected to the first phase of the adsorption study, in which the influent rate was adjusted to match the $\mathrm{K}_{\mathrm{sat}}$ of each of the media.

In the laboratory setup (Figure 1), the column acts as an infiltration based system (P) and the pumped water from the tank represents the urban runoff from impervious surfaces (I). The ratio between impervious to pervious area $(\mathrm{I} / \mathrm{P})$ is often used to size such filters [24,25]. In areas with a high percentage of impervious surfaces such as roads, sidewalks, roofs, etc., an empirical runoff coefficient (C) close to 1 can be assumed.

Equation (1), which is based on the rational method, allows for calculating the ideal storm intensity (SI) in $(\mathrm{mm} / \mathrm{h})$ that will generate the HLR in $(\mathrm{mm} / \mathrm{h})$ applied on the columns through the peristaltic pump. For a certain hydraulic load, the intensity of the storm event is indirectly linked to the size of the fictitious catchment feeding the columns (I).

$$
\mathrm{SI}=\frac{\mathrm{HLR}}{\mathrm{C} \cdot \mathrm{I} / \mathrm{P}}
$$

\subsection{Expected Service Life}

The results from the second phase were used to estimate cumulative adsorption capacities of the different adsorbent amended filters for the target metals under the given conditions. The cumulative adsorption for each metal, $\mathrm{q}(\mathrm{mg} / \mathrm{kg})$, was obtained from Equation (2).

$$
\mathrm{q}=\frac{\int_{0}^{\mathrm{Vd}}(\mathrm{Ci}-\mathrm{Ce}) \cdot \mathrm{dV}}{\mathrm{M}}
$$

where $\mathrm{Ci}$ is the influent concentration $(\mathrm{mg} / \mathrm{L}), \mathrm{Ce}$ is the effluent concentration $(\mathrm{mg} / \mathrm{L}), \mathrm{Vd}$ is the cumulative volume passed until a certain \% removal (L), and $\mathrm{M}$ is the amount of material in the filter (kg).

Expected cumulative pollutant retention $(\mathrm{mg})$ was obtained as the product of the area of the filter, density, filter depth, and $\mathrm{q}$ at the required removal. Expected pollutant input load (mg/year) was obtained as the product of the average dissolved pollutant concentration measured at local streets, annual precipitation depth, area of the tributary catchment, and a volume capture factor of 0.9 , based on international design guidelines. The expected service life (years) was obtained, dividing the expected cumulative pollutant retention at a required removal by the pollutant load expected to be treated by the filtration facility. 


\section{Results and Discussion}

\subsection{Control of Flowrate, First Phase}

In this phase, flow rate was controlled and frequent sampling performed to collect enough data to evaluate the performance in the short term of the different filters under high hydraulic loads.

\subsubsection{Metal Removal by Adsorbent Amended Filters}

Figure 2 presents the percentage removal of the four target metals, by three adsorbent amended filters for stormwater, as a function of pore volume of synthetic stormwater passed through the filter. In this study, one pore volume equaled to $1600 \mathrm{~cm}^{3}$ approx. and corresponded to the volume occupied by voids in a certain column. It varied from column to column because of different materials, bulk densities and different porosities. From the curves in Figure 2, it is clear that all of the adsorbent amended filters had a very high removal rates (>99\% in case of $\mathrm{Pb}$ ) even under considerable high hydraulic loads. There are some fluctuations and variations in the adsorption behavior of $\mathrm{Cu}$ and $\mathrm{Zn}$ both on the pine bark and the olivine amended filter, which could be due to variable flow patterns inside the gravity based filter. The gentle increasing trend for removal of these two metals on pine bark and olivine points to time dependency of adsorption reactions. However, in contrast to $\mathrm{Pb}, \mathrm{Cu}$ and $\mathrm{Zn}$, the removal of $\mathrm{Ni}$ did not follow the same pattern in the case of the filter amended with charcoal. The decrease of Ni removal with increasing water passed indicates that Ni has a relatively low affinity for the charcoal, and with increasing volume of passed water the competition for the sites may also have increased. Nevertheless, with the exception of charcoal vis-à-vis $\mathrm{Ni}$, the fluctuations in removal of metals $( \pm 1 \%-2 \%)$ on the rest of the adsorbents were small, which demonstrates that the presented filters would perform robustly in the actual conditions.

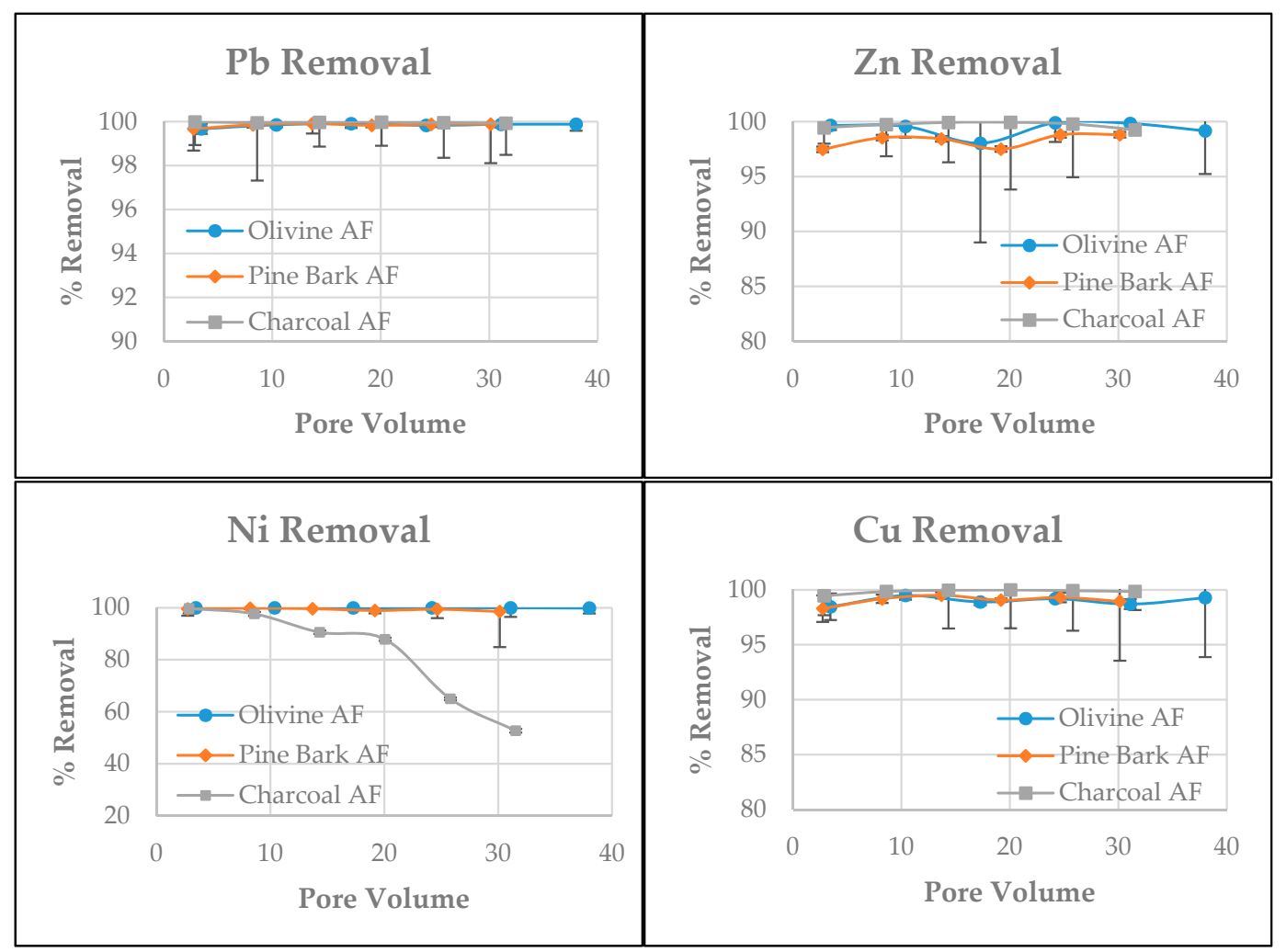

Figure 2. Percentage removal of the four toxic metals as a function of pore volume. Note that the Y-axis is different in each case. AF stands for amended filter. 


\subsubsection{Desorption of Metals Due to Salts}

The columns were fed with synthetic stormwater continuously for approx. $14 \mathrm{~h}$ (time to reach a liquid to solid ratio of 11), then one of the two replicate columns was taken apart to study the influence of salt application on desorption of already adsorbed metals. Table 5 shows the results of metal release (in percentage) from the columns as a function of pore volume. The results show that the saline solution had variable effects on the three adsorbent amended filters and the four metals. A small release of metals $(<3 \%)$ was observed in most of the filters. This relative low release indicates that the adsorption was stable and salts would not have a major influence on the metal release rates. This finding is in agreement with [26], which have shown that $\mathrm{NaCl}$ has the lowest impact on the desorption of already mobilized metals compared with other studied deicers. Additionally, [20,27] reported that metals adsorbed on soils designed for bioretention were scarcely leached due to $\mathrm{NaCl}$ applications and, therefore, retention under cold climate conditions is likely to be effective for the studied purpose. However, [28] detected a significant impact of salt addition on the removal of dissolved $\mathrm{Pb}$ and $\mathrm{Cu}$, which might be due to the fact that the salt favors dissolution of organic matter which has a strong affinity of these metals. In the present study, a high release of $\mathrm{Ni}(9 \%-15 \%)$ from the charcoal amended filter was detected. This behavior might be due to the fact that charcoal has been found to have quite low affinity for the $\mathrm{Ni}$, which allows $\mathrm{Na}$ to replace it easily through ion exchange. Furthermore, binding forces of adsorbed cations are also dependent on hydrated radius of the divalent ions as well as relative concentrations, which means that sodium, due to smaller hydrated radius and larger concentrations, will face optimal conditions for replacing adsorbed $\mathrm{Ni}$.

The release behavior with regards to the same metal differs from adsorbent to adsorbent. As an example, $\mathrm{Ni}$, which shows an increasing trend both in the case of the charcoal and the olivine amended filter, is decreasing with increasing pore volume in the case of the filter amended with pine bark. However, common aspects among adsorbents are observed, for example, extremely low release of $\mathrm{Pb}$. This might indicate that $\mathrm{Pb}$ is difficult to exchange because of having smaller hydrated radius and hence being more strongly adsorbed to the site of the negative charge. Moreover, $\mathrm{Pb}$ might form inner sphere complexes with the charge sites, which further reduces the chances of $\mathrm{Pb}$ adsorption reversing itself. Similarly, $\mathrm{Ni}, \mathrm{Zn}$, and $\mathrm{Cu}$ mobilization from the olivine and the charcoal amended filter follow a gentle increasing trend with pore volume. This shows that their desorption is dependent on the exchange process with $\mathrm{Na}$. Nonetheless, with the exception of $\mathrm{Ni}$, the release of metals from all presented filters is below 3\%, which is an encouraging aspect as this indicates that a minimal environmental impact can be expected in full scale systems.

Table 5. Percentage desorption of four metals as a function of pore volume from three alternative filters. Note that the pore volumes are different in each case. NA stands for not available and AF for amended filter.

\begin{tabular}{|c|c|c|c|c|c|c|c|c|c|c|c|c|c|c|}
\hline \multirow{2}{*}{$\begin{array}{c}\text { Pore } \\
\text { Volume }\end{array}$} & \multicolumn{4}{|c|}{ Charcoal AF } & \multirow{2}{*}{$\begin{array}{c}\text { Pore } \\
\text { Volume }\end{array}$} & \multicolumn{4}{|c|}{ Olivine AF } & \multirow{2}{*}{$\begin{array}{c}\text { Pore } \\
\text { Volume }\end{array}$} & \multicolumn{4}{|c|}{ Pine Bark AF } \\
\hline & $\begin{array}{l}\mathrm{Pb} \\
(\%)\end{array}$ & $\begin{array}{c}\mathrm{Ni} \\
(\%)\end{array}$ & $\begin{array}{l}\mathrm{Cu} \\
(\%)\end{array}$ & $\begin{array}{l}\mathrm{Zn} \\
(\%)\end{array}$ & & $\begin{array}{l}\mathrm{Pb} \\
(\%)\end{array}$ & $\begin{array}{l}\mathrm{Ni} \\
(\%)\end{array}$ & $\begin{array}{l}\mathrm{Cu} \\
(\%)\end{array}$ & $\begin{array}{l}\mathrm{Zn} \\
(\%)\end{array}$ & & $\begin{array}{l}\mathrm{Pb} \\
(\%)\end{array}$ & $\begin{array}{c}\mathrm{Ni} \\
(\%)\end{array}$ & $\begin{array}{l}\mathrm{Cu} \\
(\%)\end{array}$ & $\begin{array}{l}\mathrm{Zn} \\
(\%)\end{array}$ \\
\hline 2.8 & $<0.01$ & 9.37 & 0.04 & 0.17 & 3.4 & $<0.01$ & 0.06 & 0.41 & 0.20 & 2.7 & 0.02 & 2.15 & 0.23 & 2.78 \\
\hline 8.6 & $<0.01$ & 7.72 & 0.12 & 0.53 & 10.3 & $<0.01$ & 0.07 & 0.27 & 0.21 & 8.2 & 0.03 & 2.62 & 0.35 & 2.72 \\
\hline 14.3 & 0.01 & 5.57 & 0.09 & 0.32 & 17.3 & 0.01 & 0.23 & 0.49 & 1.89 & 13.7 & 0.04 & 1.73 & 0.34 & 1.39 \\
\hline 20 & 0.01 & 15.26 & 0.11 & 0.49 & 24.2 & 0.02 & 0.26 & 1.13 & 2.02 & 19.2 & 0.02 & 1.19 & 0.24 & 1.43 \\
\hline 25.8 & 0.03 & 9.65 & 0.11 & 0.36 & 31 & 0.01 & 0.34 & 1.06 & 2.09 & 24.6 & 0.04 & 2.06 & 0.31 & 1.65 \\
\hline 31.5 & 0.01 & 11.64 & 0.14 & 0.41 & 38 & NA & NA & NA & NA & 30.1 & 0.02 & 1.91 & 0.41 & 1.28 \\
\hline
\end{tabular}

\subsubsection{Simulating Storm Events}

Table 6 shows that, in the case of the charcoal amended filter, the hydraulic rate applied to the columns corresponds with the runoff generated by a storm event with an intensity of $12 \mathrm{~mm} / \mathrm{h}$. This storm intensity is slightly higher than a two year return period and one hour duration storm event in the city of Trondheim (10.7 mm/h). In other words, if this event fell in an impervious catchment 
50 times bigger than the facility $(\mathrm{I} / \mathrm{P}=50)$, it could be handled by this filter without ponding. On the other hand, the filter composed with pine bark and sand would only be able to manage completely a storm intensity of $8.5 \mathrm{~mm} / \mathrm{h}$ for the same tributary catchment. The clogging process, which will have a negative impact on the actual infiltration capacity in a field application, was not considered in the calculations. However, $\mathrm{K}_{\text {sat }}$ values, which were used to dimension these systems, may counterbalance the clogging risk because these values represent a conservative estimate of the potential infiltration rate [29].

Table 6. Hydrological approach using formula 1 during the first phase of the adsorption test. PS stands for pump speed, HLR for hydraulic loading rate, I/P for impervious to pervious ratio, SI for storm intensity, and $\mathrm{AF}$ for amended filter. $\mathrm{C}$ is the empirical runoff coefficient.

\begin{tabular}{ccccc}
\hline Filter & PS (mL/min) & HLR $(\mathbf{c m} / \mathbf{h})$ & I/P & SI $(\mathbf{m m} / \mathbf{h})$ if C $=\mathbf{0 . 9}$ \\
\hline Charcoal AF & 72.2 & 55 & 50 & 12 \\
Olivine AF & 58.7 & 45 & 50 & 9.9 \\
Pine bark AF & 51.1 & 39 & 50 & 8.5 \\
\hline
\end{tabular}

\subsection{Control of Volumes. Second Phase}

In this phase, high loading was simulated by passing large volumes (approx. $2500 \mathrm{~L}$ per column) to study the long-term performance of the adsorbents.

\section{Metal Removal by Adsorbent Amended Filters}

In Figures 3-5, the results regarding removal of the target metals over increasing pore volume are shown. Looking at the results, complete exhaustion was only observed in the filter amended with charcoal for Ni. The filter composed of charcoal and sand showed the lowest affinity for the target metals, which is in agreement with results from a similar study [26]. In contrast, the olivine amended filter was still achieving 50\% removal for all four metals.

Figure 3 shows that, in the case of the filter amended with olivine, the removal curves of all target metals follow a non-linear decreasing trend. The removal of $\mathrm{Pb}, \mathrm{Ni}$, and $\mathrm{Zn}$ shows a sharp decrease after 1200 pore volumes. This might indicate that spherical shape allows the influent to bypass the olivine surfaces. Furthermore, spherical shapes limit the exposed surface, which as it becomes covered with metals starts to release some into the solution. Additionally, adsorption and desorption might have operated simultaneously due to the length of the experiment as well as fluctuations in the flow rate. The use of olivine as adsorbent for dissolved metals is relatively new, and the nature of its charge sites/surface functional groups, and removal mechanisms under different experimental conditions have not been fully evaluated yet. Therefore, to elucidate main metal removal mechanisms of olivine and their variability in response to operational factors would require further detailed investigation.

In the case of pine bark (Figure 4), the shapes of the curves for $\mathrm{Pb} / \mathrm{Cu}$ and $\mathrm{Ni} / \mathrm{Zn}$ are different. $\mathrm{Pb}$ and $\mathrm{Cu}$ showed a high removal percentage, $83 \%$ and $77 \%$ respectively, after more than 1500 pore volumes. However, Ni adsorption was close to exhaustion (Figure $4 \mathrm{~b}$ ), which would control the operational life even though it still has very high affinity for uptake of $\mathrm{Pb}$ and $\mathrm{Cu}$. A similar adsorption sequence for pine bark and the studied heavy metals have been previously reported in a batch study [30].

Unlike the other adsorbents, pine bark has lower surface area but achieved a high removal of metals. This can be attributed to different adsorption mechanism on pine bark, which has been attributed to compounds such as pectin, lignin, and tannin [31] that provide carboxylic, phenolic, and hydroxyl groups for the adsorption of metals. On the other hand, pine bark is prone to leaching of some of these organic compounds and dissolved organic carbon (DOC), which can interfere with the adsorption process due to complexation of dissolved metals such as $\mathrm{Cu}$ with DOC [22]. Several treatments have been reported in the literature to prevent the release of soluble organics, which 
can color and contaminate the effluent [32]. However, additional treatments can also reduce the attractiveness of pine bark amended filters due to increased costs associated with pre-treatment and/or post-treatment disposal of chemicals.

For the charcoal amended filter (Figure 5), the removal of metals, with the exception of $\mathrm{Cu}$ and $\mathrm{Pb}$, decreased sharply within the first 200 pore volumes. For reduced adsorption of $\mathrm{Zn}$ and $\mathrm{Ni}$ as compared to the other two metals, variable binding mechanisms, competition from other cations and dissolved organic carbon in tap water, could be the probable cause. A previous study [33] reported that $\mathrm{Pb}$ and $\mathrm{Cu}$ formed covalent or strong bonds with biosorbents. However, $\mathrm{Ni}$ and $\mathrm{Zn}$ generally adsorb on weak electrostatic binding sites. This kind of binding behavior can result in reduced adsorption for certain metals if there is a competition from other ions (i.e., $\mathrm{Ca}^{2+}$ ). However, the concentration of $\mathrm{Ca}^{2+}$ in our synthetic stormwater was substantially low to have caused any substantial interference in the adsorption of metals on charcoal.

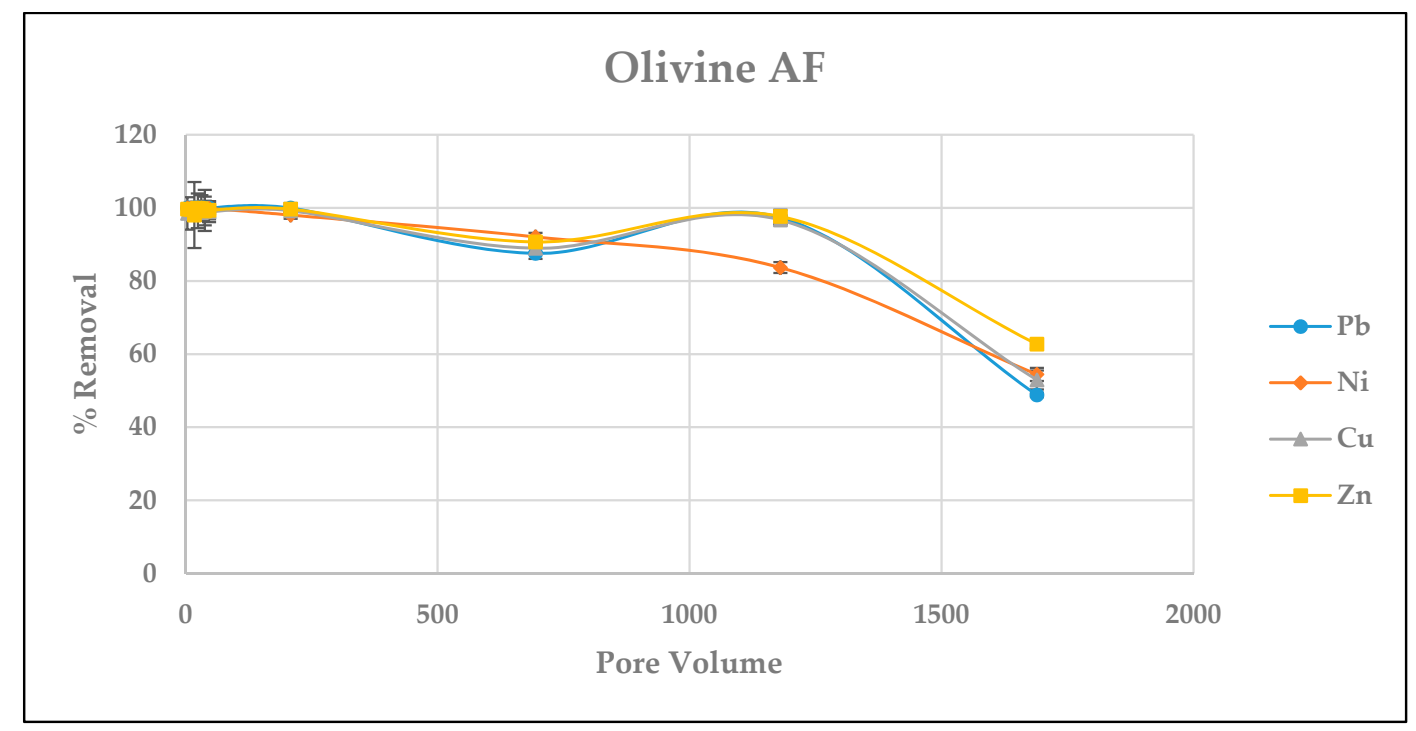

Figure 3. Percentage removal of the four metals by olivine amended filters as a function of pore volume. AF stands for amended filter.

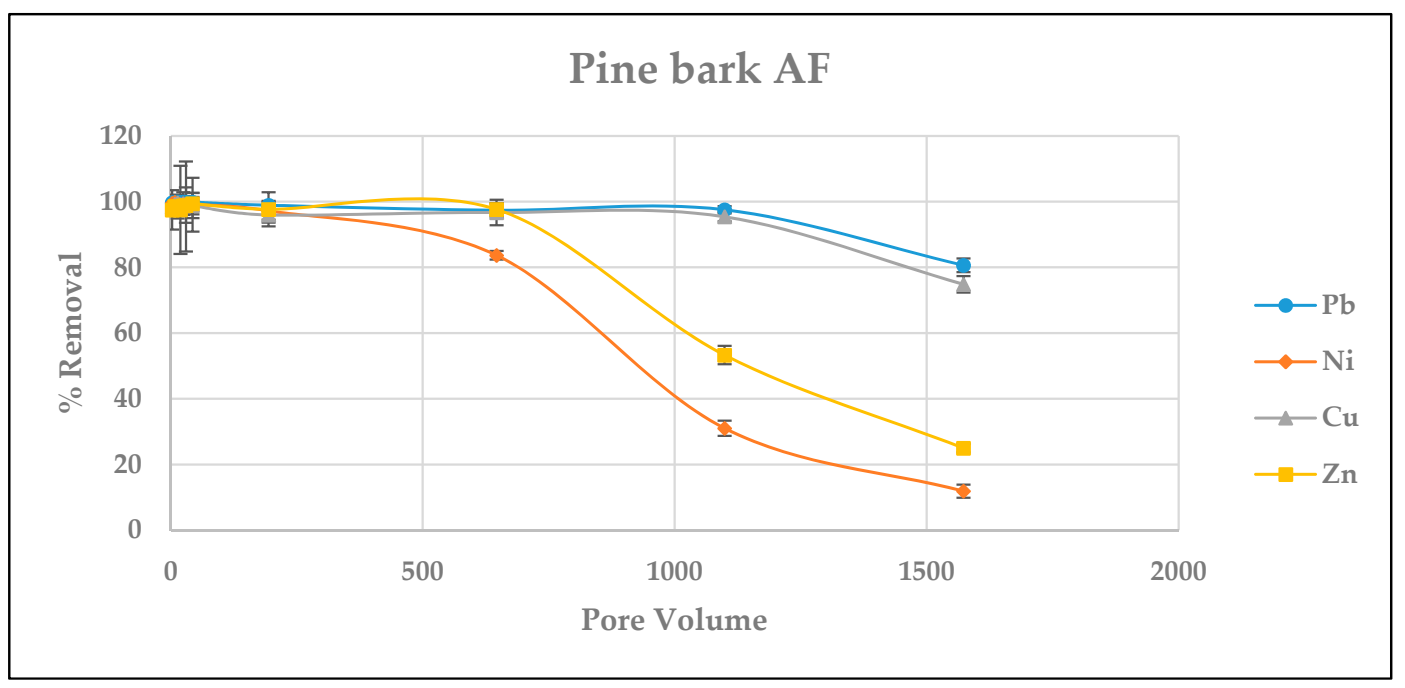

(a)

Figure 4. Cont. 


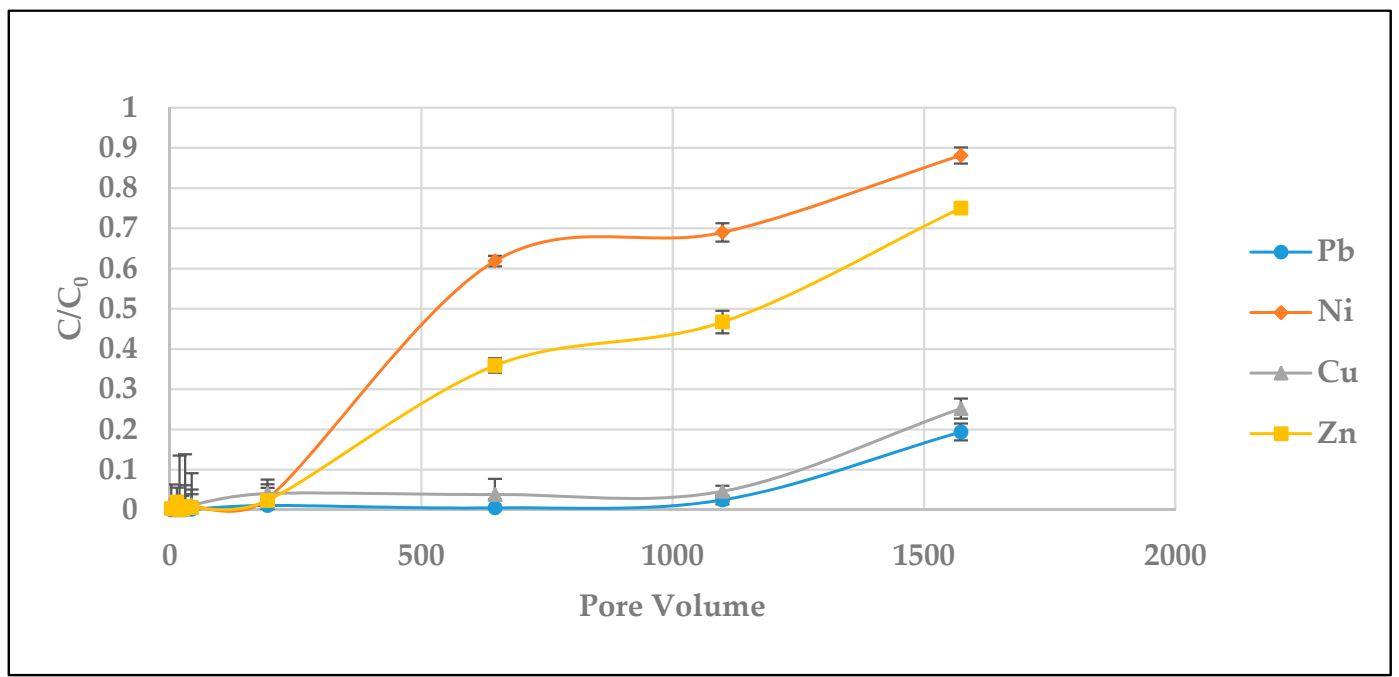

(b)

Figure 4. Percentage removal (a) and breakthrough curve (b) of the four metals by pine bark amended filters as a function of pore volume. AF stands for amended filter. $\mathrm{C}$ and $\mathrm{C}_{0}$ are the effluent and influent metal concentrations, respectively.

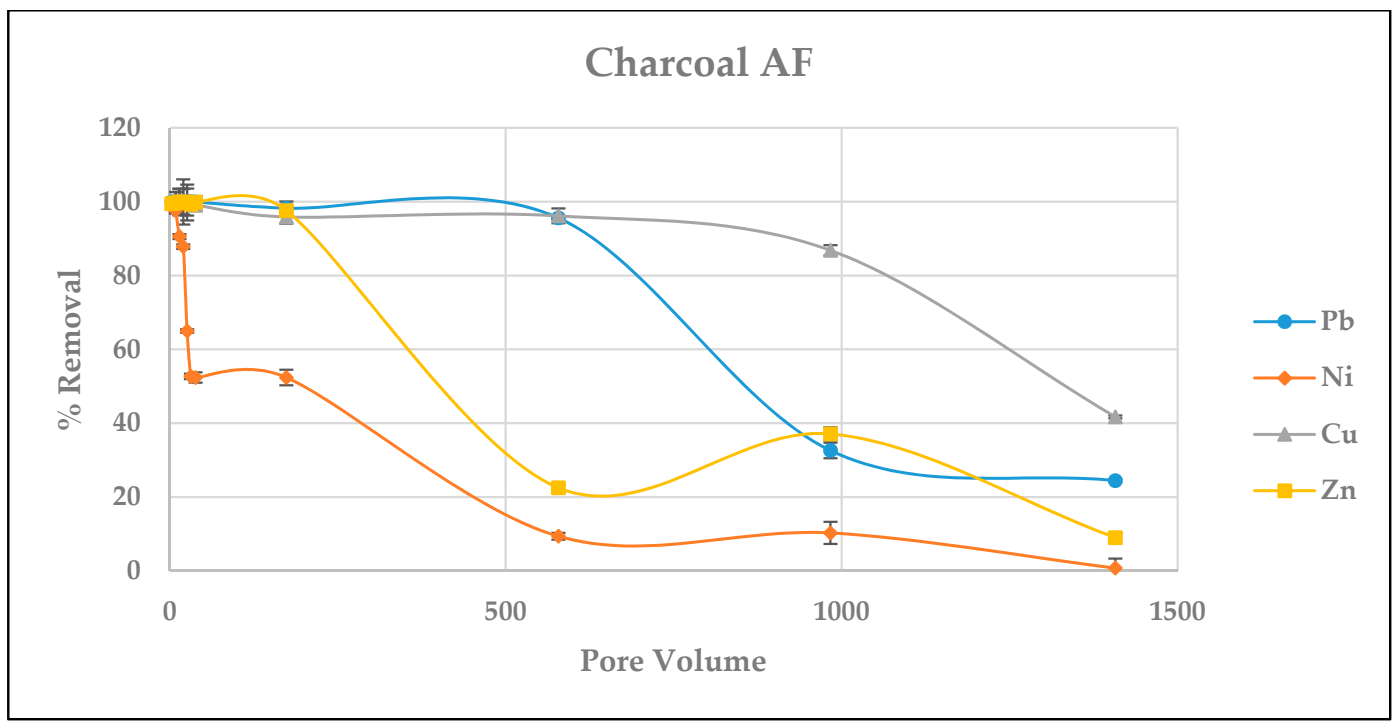

Figure 5. Percentage removal of the four metals by charcoal amended filters as a function of pore volume. AF stands for amended filter.

The low removal of Ni by charcoal could also be due to the $\mathrm{pH}$ of the inflow solution, at 7.5, while optimal $\mathrm{Ni}$ adsorption occurs at $\mathrm{pH} 6$ [34]. However, coal based adsorbent, as in this case, has point of zero charge at $\mathrm{pH} 7.2$ [35], which is close to the $\mathrm{pH}$ of the influent. Therefore, the $\mathrm{pH}$ conditions are favorable for cationic metal adsorption. Another reasonable explanation for low Ni adsorption could also be due to the nature of the adsorbent, which is derived from a metamorphic source-anthracite charcoal. Fourier transform infrared spectroscopy (FTIR) data from [36] showed that anthracite based carbons contain low oxygen surface functional groups, which can affect adsorption of metals such as $\mathrm{Ni}$. Additionally, adsorption of $\mathrm{Ni}$ has been reported to be several orders of magnitude lower than other metals such as $\mathrm{Cu}$ at $\mathrm{pH}<8$ [37]. $\mathrm{Zn}$ and $\mathrm{Pb}$ showed initially high affinity but it declined over time, which indicates saturation of adsorption capacities of these two metals or increased competition for limited binding sites. This emphasizes the metamorphic nature of charcoal as suitable for removal 
of $\mathrm{Cu}, \mathrm{Pb}$, and $\mathrm{Zn}$ but not for $\mathrm{Ni}$. The life span of the charcoal amended filter will be controlled by $\mathrm{Ni}$ because it showed the earliest breakthrough, which is in agreement with a previous study using charcoal for metal removal [26].

\subsection{Estimating Service Life}

Estimated service life of the studied filters with respect to the target metals are presented in Table 7. For the calculations, a density of $1.600 \mathrm{~kg} / \mathrm{m}^{3}$, a filter depth of $40 \mathrm{~cm}$, an average total precipitation depth of $895 \mathrm{~mm} /$ year for Trondheim area, and a 90\% runoff capture were considered. Additionally, allowable release concentrations from the filters were adopted based on Norwegian quality standards for moderate contamination of the receiving surface waters. The input dissolved concentrations were based on average runoff concentrations detected in the streets of Trondheim [38].

Table 7. Cumulative adsorption at the required removal and service life in (years) for different filters with respect to the target metals. I/P stands for impervious area to pervious area ratio and AF for amended filter.

\begin{tabular}{ccccccc}
\hline \multirow{2}{*}{ I/P Ratio } & \multirow{2}{*}{$\begin{array}{c}\text { Target } \\
\text { Metal }\end{array}$} & $\begin{array}{c}\text { Runoff } \\
\text { Concentration }(\mu \mathrm{g} / \mathbf{L})\end{array}$ & $\begin{array}{c}\text { Required } \\
\text { Removal (\%) }\end{array}$ & \multicolumn{3}{c}{$\begin{array}{c}\text { Cumulative Adsorption }(\mathbf{m g} / \mathbf{k g}) \text { and Service } \\
\text { Life in Brackets }\end{array}$} \\
\cline { 5 - 7 } & & & & Pine Bark AF & Charcoal AF & Olivine AF \\
\hline \multirow{2}{*}{$\mathbf{5 0}$} & $\mathbf{Z n}$ & 18 & 31 & $9.1(9)$ & $2.3(2.3)$ & $2.5(2.5)$ \\
& $\mathbf{C u}$ & 13.5 & 92 & $9.8(13)$ & $3.1(4)$ & $1.1(1.5)$ \\
& $\mathbf{N i}$ & 2.32 & 35 & $6.1(46)$ & $0.6(5)$ & $2.4(18)$ \\
\hline \multirow{2}{*}{$\mathbf{2 0}$} & $\mathbf{Z n}$ & 18 & 31 & $9.1(22)$ & $2.3(5.5)$ & $2.5(6)$ \\
& $\mathbf{C u}$ & 13.5 & 92 & $9.8(32)$ & $3.1(10)$ & $1.1(3.8)$ \\
& $\mathbf{N i}$ & 2.32 & 35 & $6.1(115)$ & $0.6(12)$ & $2.4(45)$ \\
\hline
\end{tabular}

From the values in Table 7, it can be seen that zinc generally will determine the service life of the filters amended with pine bark or charcoal due to high concentrations detected in urban runoff as well as the moderate affinity with the adsorbents (Figures 3-5). On the other hand, copper was found to determine the service life of the olivine amended filter due to the low cumulative adsorption observed at the required removal combined with relatively high runoff concentration. Nickel showed low affinity with all the adsorbents although the removal requirement was more relaxed, which allows these filters to stand during longer periods. Lead was not considered in the calculations because the observed concentrations in local runoff was lower than Norwegian standards for receiving surface waters, indicating that no treatment would be required. Therefore, this element will not pose a risk for the receiving water body, regardless of the removal acquired in the filter. On the other hand, I/P ratios set by the planners will influence the service life of the filters because it will modify the relation between the pollutant input load and the mass of the filter. A higher ratio means a larger tributary providing pollution into the facility, which will cause the filter to reach the removal requirement earlier and, subsequently, its service life.

\section{Conclusions}

The results presented in this study demonstrate the potential of the studied adsorbents for use in treatment filters for urban and highway runoff, both from a removal and a volume mitigation point of view. In terms of removal performance, the pine bark and the olivine amended filters showed the best affinity with the target metals. To mitigate the poor performance of pine bark with respect to $\mathrm{Ni}$ and $\mathrm{Zn}$ removal and the higher cost of olivine, it appears attractive to explore the combined use of these two adsorbents. Charcoal showed the lowest affinity for the target metals among all the adsorbents. However, the final choice of adsorbent should also consider infiltration performance, initial costs, need for maintenance, material stability, potential leaching of other pollutants, etc., and not just the removal performance criterion. The hydraulic loading rates used were considerably high in comparison with other similar studies. Despite higher rates, satisfactory pollution removal was 
achieved, which highlights the outstanding metal removal under infrequent storm events such as two years return period one hour duration events for the city of Trondheim. In terms of environmental impact, all the filters showed very little release of metals in response to addition of $\mathrm{NaCl}$ as deicer. However, $\mathrm{Ni}$ was to a greater extent leached from charcoal due to low affinity with this adsorbent as well as competition with sodium. From the point of view of the effluent discharge, $\mathrm{Zn}$ was shown to determine the service life of filters amended with charcoal or pine bark, and $\mathrm{Cu}$ did the same for the service life of olivine. Furthermore, the filter composed of pine bark and sand showed the largest values ranging from nine years to more than 100 depending on the target element as well as the size of the tributary. It must be highlighted that laboratory conditions differ from real field conditions; hence, it is recommended that these values be used as a general indication of their potential service life. Nonetheless, these results can be a useful tool to discard materials for subsequent experiments, as well as providing a general understanding of the factors influencing the service life of the studied filters. Additionally, it is recommended to couple these filters with a pre-sedimentation basin in order to reduce high input loads of sediments that might clog top layers and hinder further adsorption processes. Finally, these filters should be tested in field scale experiments to further study hydraulics and removal performance for practical design guidelines.

Acknowledgments: The authors wish to acknowledge the National Public Road Administration (Vegvesen) of Norway for their financial support for this project.

Author Contributions: Carlos Monrabal-Martinez, Aamir Ilyas, and Tone M. Muthanna conceived and designed the experiments. Carlos Monrabal-Martinez and Aamir Ilyas performed the experiments and analyzed the data. Carlos Monrabal-Martinez, Aamir Ilyas, and Tone M. Muthanna wrote the manuscript.

Conflicts of Interest: The authors declare no conflict of interest.

\section{References}

1. LeFevre, G.H.; Paus, K.H.; Natarajan, P.; Gulliver, J.S.; Novak, P.J.; Hozalski, R.M. Review of dissolved pollutants in urban storm water and their removal and fate in bioretention cells. J. Environ. Eng. 2015, 141, 04014050. [CrossRef]

2. Hunt, W.F.; Davis, A.P.; Traver, R.G. Meeting hydrologic and water quality goals through targeted bioretention design. J. Environ. Eng. 2012, 138, 698-707. [CrossRef]

3. Roy-Poirier, A.; Champagne, P.; Filion, Y. Review of bioretention system research and design: Past, present, and future. J. Environ. Eng. 2010, 136, 878-889. [CrossRef]

4. Ahiablame, L.M.; Engel, B.A.; Chaubey, I. Effectiveness of low impact development practices: Literature review and suggestions for future research. Water Air Soil Pollut. 2012, 223, 4253-4273. [CrossRef]

5. Cizek, A.R.; Hunt, W.F. Defining predevelopment hydrology to mimic predevelopment water quality in stormwater control measures (SCMS). Ecol. Eng. 2013, 57, 40-45. [CrossRef]

6. Blecken, G.-T.; Zinger, Y.; Deletić, A.; Fletcher, T.D.; Viklander, M. Influence of intermittent wetting and drying conditions on heavy metal removal by stormwater biofilters. Water Res. 2009, 43, 4590-4598. [CrossRef] [PubMed]

7. Muthanna, T.; Viklander, M.; Gjesdahl, N.; Thorolfsson, S. Heavy metal removal in cold climate bioretention. Water Air Soil Pollut. 2007, 183, 391-402. [CrossRef]

8. Helmreich, B.; Hilliges, R.; Schriewer, A.; Horn, H. Runoff pollutants of a highly trafficked urban road-Correlation analysis and seasonal influences. Chemosphere 2010, 80, 991-997. [CrossRef] [PubMed]

9. Huber, M.; Welker, A.; Helmreich, B. Critical review of heavy metal pollution of traffic area runoff: Occurrence, influencing factors, and partitioning. Sci. Total Environ. 2016, 541, 895-919. [CrossRef] [PubMed]

10. Kalmykova, Y.; Knutsson, J.; Strömvall, A.-M.; Hargelius, K. Blast-furnace sludge as sorbent material for multi-metal contaminated water. In Highway and Urban Environment; Rauch, S., Morrison, G.M., Monzón, A., Eds.; Springer: Dordrecht, The Netherlands, 2010; Volume 17, pp. 307-317.

11. Kietlińska, A.; Renman, G. An evaluation of reactive filter media for treating landfill leachate. Chemosphere 2005, 61, 933-940. [CrossRef] [PubMed] 
12. Kalmykova, Y.; Stromvall, A.M.; Steenari, B.M. Alternative materials for adsorption of heavy metals and petroleum hydrocarbons from contaminated leachates. Environ. Technol. 2008, 29, 111-122. [CrossRef] [PubMed]

13. Paus, K.H.; Morgan, J.; Gulliver, J.S.; Hozalski, R.M. Effects of bioretention media compost volume fraction on toxic metals removal, hydraulic conductivity, and phosphorous release. J. Environ. Eng. 2014, 140, 04014033. [CrossRef]

14. Davis, A.P.; Shokouhian, M.; Sharma, H.; Minami, C. Laboratory study of biological retention for urban stormwater management. Water Environ. Res. Res. Publ. Water Environ. Fed. 2001, 73, 5-14. [CrossRef]

15. Li, Y.; Helmreich, B. Simultaneous removal of organic and inorganic pollutants from synthetic road runoff using a combination of activated carbon and activated lignite. Sep. Purif. Technol. 2014, 122, 6-11. [CrossRef]

16. Huber, M.; Welker, A.; Dierschke, M.; Drewes, J.E.; Helmreich, B. A novel test method to determine the filter material service life of decentralized systems treating runoff from traffic areas. J. Environ. Manag. 2016, 179, 66-75. [CrossRef] [PubMed]

17. Ilyas, A.; Muthanna, T.M. Assessment of upscaling potential of alternative adsorbent materials for highway stormwater treatment in cold climates. Environ. Technol. 2016, 38, 705-717. [CrossRef] [PubMed]

18. Paus, K.H.; Braskerud, B.C. Suggestions for designing and constructing bioretention cells for a nordic climate forslag til dimensjonering OG utforming AV regnbed for nordiske forhold. J. Water Manag. Res. 2014, 70, 139-150.

19. Monrabal-Martinez, C.; Ilyas, A.; Muthanna, T.M. Study of infiltration performance of roadside filters with adsorbent media for catchment and filter sizing. In Proceeding of the 12th Urban Environment Symposium, Oslo, Norway, 1-3 June 2015.

20. Paus, K.H.; Morgan, J.; Gulliver, J.S.; Leiknes, T.; Hozalski, R.M. Effects of temperature and nacl on toxic metal retention in bioretention media. J. Environ. Eng. 2014, 140, 04014034. [CrossRef]

21. Blecken, G.-T.; Marsalek, J.; Viklander, M. Laboratory study of stormwater biofiltration in low temperatures: Total and dissolved metal removals and fates. Water Air Soil Pollut. 2010, 219, 303-317. [CrossRef]

22. Huber, M.; Badenberg, S.; Wulff, M.; Drewes, J.; Helmreich, B. Evaluation of factors influencing lab-scale studies to determine heavy metal removal by six sorbents for stormwater treatment. Water 2016, 8, 62. [CrossRef]

23. Sun, X.; Davis, A.P. Heavy metal fates in laboratory bioretention systems. Chemosphere 2007, 66, 1601-1609. [CrossRef] [PubMed]

24. DeBusk, K.; Wynn, T. Storm-water bioretention for runoff quality and quantity mitigation. J. Environ. Eng. 2011, 137, 800-808. [CrossRef]

25. Davis, A. Field performance of bioretention: Hydrology impacts. J. Hydrol. Eng. 2008, 13, 90-95. [CrossRef]

26. Huber, M.; Hilbig, H.; Badenberg, S.C.; Fassnacht, J.; Drewes, J.E.; Helmreich, B. Heavy metal removal mechanisms of sorptive filter materials for road runoff treatment and remobilization under de-icing salt applications. Water Res. 2016, 102, 453-463. [CrossRef] [PubMed]

27. Chris, D.; Andrea, B.; Jennifer, D. Bioretention: Assessing effects of winter salt and aggregate application on plant health, media clogging and effluent quality. Water Qual. Res. J. Can. 2013, 48, 387-399.

28. Søberg, L.C.; Viklander, M.; Blecken, G.-T. The influence of temperature and salt on metal and sediment removal in stormwater biofilters. Water Sci. Technol. 2014, 69, 2295. [CrossRef] [PubMed]

29. Paus, K.H.; Morgan, J.; Gulliver, J.S.; Leiknes, T.; Hozalski, R.M. Assessment of the hydraulic and toxic metal removal capacities of bioretention cells after 2 to 8 years of service. Water Air Soil Pollut. 2013, 225, 1803. [CrossRef]

30. Cutillas-Barreiro, L.; Ansias-Manso, L.; Fernández-Calviño, D.; Arias-Estévez, M.; Nóvoa-Muñoz, J.C.; Fernández-Sanjurjo, M.J.; Álvarez-Rodríguez, E.; Núñez-Delgado, A. Pine bark as bio-adsorbent for Cd, Cu, $\mathrm{Ni}, \mathrm{Pb}$ and $\mathrm{Zn}$ : Batch-type and stirred flow chamber experiments. J. Environ. Manag. 2014, 144, 258-264. [CrossRef] [PubMed]

31. Gaballah, I.; Goy, D.; Allain, E.; Kilbertus, G.; Thauront, J. Recovery of copper through decontamination of synthetic solutions using modified barks. Metall. Mater. Trans. B 1997, 28, 13-23. [CrossRef]

32. Sen, A.; Pereira, H.; Olivella, M.A.; Villaescusa, I. Heavy metals removal in aqueous environments using bark as a biosorbent. Int. J. Environ. Sci. Technol. 2015, 12, 391-404. [CrossRef]

33. Schiewer, S.; Wong, M.H. Ionic strength effects in biosorption of metals by marine algae. Chemosphere 2000, 41, 271-282. [CrossRef] 
34. Pawluk, K.; Fronczyk, J. Removal of dissolved metals by activated carbon from road runoff in batch systems_Equilibrium and kinetic. Ann. Wars. Univ. Life Sci. Land Reclam. 2015, 47, 31-42. [CrossRef]

35. Chen, P.J.; Lin, M. Equilibrium and kinetics of metal ion adsorption onto a commercial h-type granular activated carbon: Experimental and modeling studies. Water Res. 2001, 35, 2385-2394. [CrossRef]

36. Liu, J.; Fan, H.; Gong, G.; Xie, Q. Influence of surface modification by nitric acid on activated carbon's adsorption of nickel ions. Mater. Sci. Forums 2013, 743-744, 545-550. [CrossRef]

37. Shim, J.W.; Park, S.J.; Ryu, S.K. Effect of modification with $\mathrm{HNO}_{3}$ and naoh on metal adsorption by pitch-based activated carbon fibers. Carbon 2001, 39, 1635-1642. [CrossRef]

38. Monrabal-Martinez, C.; Muthanna, T.M.; Meyn, T. Seasonal Variation in Pollutant Concentrations and Particle Size Distribution in Urban Stormwater-Design Implications for BMPS; Novatech: Lyon, France, 2016.

(C) 2017 by the authors. Licensee MDPI, Basel, Switzerland. This article is an open access article distributed under the terms and conditions of the Creative Commons Attribution (CC BY) license (http:/ / creativecommons.org/licenses/by/4.0/). 